\author{
T.Kh. Makazhanova, A.S. Bazylzhanova, O.I. Ulbrikht \\ Ye.A. Buketov Karaganda State University, Kazakhstan \\ (E-mail: aiger111086@mail.ru)
}

\title{
The structure of normal subsets of polyhedral cone
}

\begin{abstract}
The structure of normal convex subsets of polyhedral cone $K$ in normalized space is in investigated. The normality of the subset $\Omega \subset K$ (in the sense of the cone $K$ ) is determined by the condition $\overline{\Omega-K} \cap K=\Omega$ (a line over a set means taking a topological closure). The conical shell of finite number of rays mean the polyhedrons of the cone, which are extreme rays. The structure of normal sets were studied from the geometric point of view. It is shown that every normal subset $\Omega$ of a polyhedral cone can be divided into a sum of two subsets, one of which is a bounded normal subset (in the sense of some subcone in $K$ ) and the second - the subcone $K$ contained in the set $\Omega$ (it is unbounded, if $\Omega$ is unbounded).
\end{abstract}

Keywords: cone, ray, normal, conical shell, polyhedral cone, forming rays, closed set, normal subset of cone, null cone.

Let $(X,\|\quad\|)$ is the real normalized space.

For the subset of $G \subset X$ intoduce the notation: $G^{\circ}$ - interior of $G, \bar{G}-$ closure of $G, f r G$ - frontier of $G$. Everywhere $\varnothing$ - empty set.

All the operation will be entered in the space $X$ :

$$
\begin{gathered}
G_{1}+G_{2}=\left\{x=x_{1}+x_{2}, x_{1} \in G_{1}, x_{2} \in G_{2}\right\} ; \quad G_{1}, G_{2} \subset X ; \\
\alpha G=\{x=\alpha x, x \in G\}, \quad G \subset X, \quad \alpha \text { - real. }
\end{gathered}
$$

The subset $G \subset X$ is called convex, if $x=\alpha x_{1}+(1-\alpha) x_{2} \in G$ for any $x_{1}, x_{2} \in G$ и $0 \leqslant \alpha \leqslant 1$. The subset $K \subset X$ is called cone (convex), if the task is done:

$$
\begin{aligned}
& \alpha x \in K \quad \forall x \in K, \quad \alpha \geqslant 0 ; \\
& x_{1}+x_{2} \in K \quad \forall x_{1}, x_{2} \in K .
\end{aligned}
$$

It is obvious, that any cone 0 has own point $x$ and outgoing ray $L=\{\alpha x, \alpha \geqslant 0\}$ from 0 . The cone $K$ is called bodily, if $K^{\circ} \neq \varnothing$; salient, if $K \cap(-K)=\{0\}$. The conical shell $c o G$ of set $G \subset X$ is called set of elements

$$
c o G=\left\{x=\sum_{i=1}^{n} \alpha_{i} x_{i}, \quad n \text { - any natural; } \quad x_{i} \in G \quad \text { и } \quad \alpha_{i} \geqslant 0 \quad \forall i=1, \ldots, n\right\} .
$$

It is obvious that the conical shell is cone. We say it will pull on the set $G$.

If $G=\varnothing$, then we consider that $K=c o G=\{0\}$.

The cone $K([1])$ is called polyhedral, if it is cone shell of finite number of outgoing rays from 0 . According to the [2] we can see, that every polyhedral cone is closure and bodily in its linear shell. The ray $L$ of cone $K$ is called extreme ray of cone, if from equality $x=x_{1}+x_{2}$, where $x \in L, x_{1}, x_{2} \in K$, follows, that $x_{1}, x_{2} \in L$. According to the [1] we can see, that the minimal (by inclusion) set of rays, it's conical shell is cone $K$, forming the extreme rays.

The extreme rays of cone we will call forming rays. If $\left\{L_{i}\right\}_{i \in I}$ is forming rays of polyhedral cone $K,\left\{e_{i}\right\}_{i \in I}$ is units (i.e. $\left\|e_{i}\right\|=1$ ) directional vectors of this rays ( $I$ - finite set of indices), then

$$
K=\left\{x=\sum_{i \in I} \alpha_{i} e_{i}, \quad \alpha_{i} \geqslant 0 \quad \forall i \in I\right\} .
$$

Let $K$ is polyhedral cone, $\left\{L_{i}\right\}_{i \in I}$ is forming rays of cone $K$. A sub subcone $K_{1}$ of cone $K$, we will be understand that any polyhedral cone, which is formed by rays $\left\{L_{i}\right\}_{i \in I_{1} \subset I}$. If $I_{1}=\varnothing$, then the subcone, which 
determined by set of indices $I_{1}$, suppose equal to $\{0\}$. If we speak about o cone in this work we will view a polyhedral cones. Let $K$ is cone, $\left\{L_{i}\right\}_{i \in I}$ is its forming rays. For set $\Omega \subset K$ we think that

$$
\beta_{i}=\sup \left\{\beta \geqslant 0: \beta e_{i} \in \Omega\right\}, \quad i \in I .
$$

If $\Omega \cap L_{i}=\varnothing$, then we think that $\beta_{i}=0$. We say that the set $\Omega \subset K$ has a (0)- property with respect to subcone spreat on rays $\left\{L_{i}\right\}_{i \in I_{1} \subset I}$, if $0<\beta_{i}<\infty$. The set $\Omega \subset K, \quad \Omega$ is called normal (that means cone $K$ ) set, if $\Omega$ is convex and rightly the equal $\overline{\Omega-K} \cap K=\Omega$.

Note 1. Directly from the definition following, that any normal subset be closure.

Note 2. If $\Omega$ is normal subset of cone, $x \in \Omega$, the segment will

$$
[0, x]=\{\alpha x: 0 \leq \alpha \leq 1\} \subset \Omega .
$$

Its objectively that $x \in \Omega \subset K$, wherefrom $\alpha x \in K$. In other case, $\alpha x=x-(1-\alpha) x$, where $x \in \Omega$, $(1-\alpha) x \in K$, i.e. $\alpha x \in \Omega-K$, according this

$$
\alpha x \in(\Omega-K) \cap K \subset \overline{\Omega-K} \cap K=\Omega .
$$

Consider the question about structure of normal subsets of polyhedral cone.

Rightly Proposition. Let $\Omega$ is normal (not be cone) subset of cone $K \Rightarrow \Omega=G+K_{1}$, where $K_{1}$ is greatest by inclusion contained in $\Omega$ подконус $K ; G=\Omega \cap K_{2}$ (where $K_{2}$ is subset in $K$ ) and $G$ is finite normal set and it has a (0)-property with respect to cone $K_{2}$.

Proof of proposition. Let $K$ is polyhedral cone, $\left\{L_{i}\right\}_{i \in I}$ is set its forming rays.

1. We will consider the case of finite set $\Omega$, i.e. $\exists C>0:\|x\| \leq C \quad \forall x \in \Omega$.

If $\Omega=\{0\}$, then $\Omega$ is null cone, this case in proposition excluded.

Let $\Omega \neq\{0\}$, then $\forall x \in \Omega(x \neq 0)$ we have

$$
x=\sum_{i \in I} \alpha_{i} e_{i} \quad \text { end } \quad \exists \alpha_{i_{0}}>0 \text { other wise } \quad x=0 .
$$

Rightly the note $\alpha_{i_{0}} e_{i_{0}}=x-\sum_{i \neq i_{0}} \alpha_{i} e_{i}$, where from

$$
\alpha_{i_{0}} e_{0} \in(x-K) \cap K \subset(\Omega-K) \cap K \subset \overline{\Omega-K} \cap K=\Omega
$$

by the normality $\Omega$ with respect to $K$.

As $\alpha_{i_{0}} e_{0} \in \Omega$, a $\beta_{i_{0}}=\sup \left\{\beta \geqslant 0: \beta e_{i} \in \Omega\right\}$, то $\beta_{i_{0}} \geq \alpha_{i_{0}}>0$ and that's the

$$
I_{2}=\left\{i \in I: \beta_{i}>0\right\} \neq \varnothing .
$$

Let $K_{2}$ is cone with forming rays $\left\{L_{i}\right\}_{i \in I_{2}}$. Following from definition, that $\Omega$ has a (0)-property with respect to cone $K_{2}$. We will show, that $\Omega \subset K_{2}$. If suppose, that $\Omega \not \subset K_{2}$, то $\exists x \in \Omega: x \notin K_{2}$. From inclusion $x \in \Omega \subset K$ we have

$$
x=\sum_{i \in I_{2}} \alpha_{i} e_{i}+\sum_{i \in I \backslash I_{2}} \alpha_{i} e_{i} .
$$

Since $x \notin K_{2}$, then $\exists i_{0} \in I \backslash I_{2}: \alpha_{i_{0}}>0$, tnen

$$
\alpha_{i_{0}} e_{i_{0}}=x-\sum_{i \neq i_{0}} \alpha_{i} e_{i} \in(x-K) \cap K \subset \overline{\Omega-K} \cap K=\Omega,
$$

because $\beta_{i_{0}} \geq \alpha_{i_{0}}>0$, where from $i_{0} \in I_{2}$, that this is contrary to inclusion $i_{0} \in I \backslash I_{2}$, according this $\Omega \subset K_{2}$ and $G=\Omega \cap K_{2}=\Omega$.

Since $\Omega$ is finite set, we get that

$$
\beta_{i}=\sup \left\{\beta \geqslant 0: \beta e_{i} \in \Omega\right\} \leq c<\infty .
$$

According this $0<\beta_{i}<\infty$ for $\forall i \in I_{2}$, where from following, that $G=\Omega$ has a (0)-property, with respect to cone $K_{2}$. 
We have the inclusion $G \subset \overline{G-K_{2}} \cap K_{2}$ from ratio $G=\Omega \subset K_{2}$. Check the inverse inclusion. From condition of normality $\Omega$ with respect to cone $K$, i.e. the equal $\overline{\Omega-K} \cap K=\Omega$ and the inclusion $K_{2} \subset K$, we have:

$$
\overline{G-K_{2}} \cap K_{2}=\overline{\Omega-K_{2}} \cap K_{2} \subset \overline{\Omega-K} \cap K=\Omega=G .
$$

As contained in $\Omega$ the cone we take $K_{1}=\{0\}$.

2 . Now let the set $\Omega$ is undefinite. We show, that $\Omega$ contains a subcone.

By definition $\beta_{i}=\sup \left\{\beta \geqslant 0: \beta e_{i} \in \Omega\right\}, \quad \forall i \in I$, so $\exists i \in I: \beta_{i}=\infty$.

Really, if it is not, i.e. $\beta_{i}<\infty, \quad \forall i \in I$, then

$$
x=\sum_{i \in I} \alpha_{i} e_{i} \quad \text { and } \quad\|x\| \leq \sum_{i \in I} \alpha_{i} \leq \sum_{i \in I} \beta_{i}, \quad \text { где } \sum_{i \in I} \beta_{i}=\beta<\infty,
$$

i.e. $\|x\| \leq \beta \quad \forall x \in \Omega$, where we get a contradiction of undefinite of set $\Omega$.

Let $I_{1}=\left\{i \in I: \beta_{i}=\infty\right\}$, we showed, that $I_{1} \neq \varnothing$ and let $K_{1}$ is subcone with forming rays $\left\{L_{i}\right\}_{i \in I_{1}}$. We wii show, that $K_{1} \subset \Omega$.

This follows from the fact, that $\beta_{i}=\sup \left\{\beta \geqslant 0: \beta e_{i} \in \Omega\right\}=\infty$ for $\forall i \in I_{1}$, i.e. if $i \in I_{1}$ и $x=\alpha e_{i} \in L_{i}$, that $\exists \beta>\alpha: \beta e_{i} \in \Omega$, we have a ratio from note $2:\left[0, \beta e_{i}\right] \subset \Omega$.

By condition $0 \leq \alpha<\beta$, so $\alpha x \in\left[0, \beta e_{i}\right] \subset \Omega \quad \forall \alpha \geq 0$, where from the ray $L_{i}=\left\{\alpha e_{i}, \alpha \geq 0\right\} \subset \Omega$. As $\left\{L_{i}\right\}_{i \in I_{1}} \subset \Omega$ и $\Omega$ is convex, that it has cone $K_{1}$, which is formed by the rays $\left\{L_{i}\right\}_{i \in I_{1}}$.

Let $I_{2}=\left\{i \in I_{1}: 0<\beta_{i}<\infty\right\}, I_{3}=\left\{i \in I: \beta_{i}=0\right\}$, then $\forall x \in \Omega$ we have

$$
x=\sum_{i \in I_{1}} \alpha_{i} e_{i}+\sum_{i \in I_{2}} \alpha_{i} e_{i}+\sum_{i \in I_{3}} \alpha_{i} e_{i}
$$

where $\alpha_{i} \geq 0 \quad \forall i \in I$.

We will show, that $\alpha_{i}=0 \quad \forall i \in I_{3}$. If it is not, that $\exists i_{0} \in I_{3}: \alpha_{i_{0}}>0$ and

$$
\alpha_{i_{0}} e_{i_{0}}=x-\left(\sum_{i \in I_{1}} \alpha_{i} e_{i}+\sum_{i \in I_{2}} \alpha_{i} e_{i}+\sum_{i \in I_{3} \backslash i_{o}} \alpha_{i} e_{i}\right) \subset x-K \subset \Omega-K \subset \overline{\Omega-K} ;
$$

besides $\alpha_{i_{0}} e_{i_{0}} \in K$, i.e. $\alpha_{i_{0}} e_{i_{0}} \in \overline{\Omega-K} \cap K=\Omega$ (by normality $\Omega$ ).

By definition $\beta_{i_{0}}=\sup \left\{\beta \geqslant 0: \beta e_{i_{0}} \in \Omega\right\} \geq \alpha_{i_{0}}>0$, this contradicts the inclusion $i_{0} \in I_{3}$.

We shown, that for any $x \in \Omega$ we have the equal $x=\sum_{i \in I_{1}} \alpha_{i} e_{i} \in K_{1}$, i.e. $\Omega \subset K_{1}$. We have previously shown, that $K_{1} \subset \Omega$, i.e. $\Omega=K_{1}$, but on the conditions of the proposition $\Omega$ can not be cone, thereby $I_{2} \neq \varnothing$.

Now let $K_{2}$ is cone with forming $\left\{L_{i}\right\}_{i \in I_{2}}$ and $G=\Omega \cap K_{2}$.

The set $G$ is finite, how the subset of finite set $\Omega$.

Following from definition the execution for set $G(0)$-property with respect to subcone $K_{2}$. Check the normality (with respect to $K_{2}$ ) of the set $G$.

The inclusion $G \subset \overline{\left(G-K_{2}\right)}$ is obviously.

By definition $G \subset \Omega, K_{2} \subset K$, so

$$
\overline{G-K_{2}} \cap K_{2} \subset \overline{\Omega-K_{2}} \cap K_{2} \subset(\overline{\Omega-K} \cap K) \cap K_{2}=\Omega \cap K_{2}=G .
$$

Of equality $G=\overline{G \cap K_{2}} \cap K_{2}$ and convexity $G$ (as the intersection of convex sets $\Omega$ и $K_{2}$ ) we have normality $G$ with respect to $K_{2}$.

Check the equality $\Omega=G+K_{1}$. As noted, $\forall x \in \Omega$ really the note

$$
x=\sum_{i \in I_{1}} \alpha_{i} e_{i}+\sum_{i \in I_{2}} \alpha_{i} e_{i}=x_{1}+x_{2}
$$

where $x_{1}=\sum_{i \in I_{1}} \alpha_{i} e_{i} ; x_{2}=\sum_{i \in I_{2}} \alpha_{i} e_{i}$. Its true for $x_{2}=x-x_{1}$ inclusion

$$
x_{2} \in \Omega-K_{1} \subset(\Omega-K) \cap K_{2} \subset(\Omega-K) \cap K \subset \overline{\Omega-K} \cap K=\Omega ;
$$

i.e. $x_{2} \in \Omega \cap K_{2}=G$, where from $x=x_{1}+x_{2} \in K_{1}+G$, we proved the inclusion $\Omega \subset G+K_{1}$. 
On the contrary, let it $x \in G+K_{1}$, i.e. $x=x_{2}+x_{1}$, where $x_{2} \in G, x_{1} \in K$. If $x_{1}=0$, then $x=x_{2} \in G=\Omega \cap K_{2}$, i.e. $x \in \Omega$.

Now let $x_{1} \neq 0$ and $L=\left\{\alpha x_{1}, \alpha \geq 0\right\}$ is ray, which passes through the point $x_{1}$. As $K_{1}$ is cone, then $\lambda x_{1} \in K_{1} \quad \forall \lambda \geq 0, \lambda x_{1} \in K \subset \Omega \quad \forall \lambda \geq 0$ and $x_{2} \in G=\Omega \cap K_{2} \subset \Omega$, by virtue of the convexity of the set $\Omega$ contains the points $\alpha x_{2}+(1-\alpha) \lambda x_{1} 0 \leq \alpha<1$ и $\lambda \geq 0$. We suppose that $\lambda=\frac{1}{1-\alpha}$ and will get, that $\alpha x_{2}+x_{1} \in \Omega$ for $0 \leq \alpha<1$.

We consider the sequence

$$
x^{n}=\left(1-\frac{1}{n}\right) x_{2}+x_{1}, \quad x_{n} \in \Omega, \quad \text { т.к. } \quad 0 \leq 1-\frac{1}{n}<1 \quad \forall n,
$$

then $\lim _{n} x^{n}=x_{2}+x_{1} \in \Omega$ by virtue of the convexity of the set $\Omega$.

The proved inclusions $\Omega \subset G+K$ и $G+K \subset \Omega$ gave the equality $\Omega=G+K$.

\title{
References
}

1 Голдман А.Дж. Многогранные выпуклые конусы // Линейные неравенства и смежные вопросы: сб. ст. / А.Дж. Голдман, А.У. Таккер. - М.: Иностранная литература, 1959. - С. 156-161.

2 Вулих Б.З. Введение в теорию конусов в нормированных пространствах / Б.З. Вулих. - Калинин: Изд-во КГУ, 1977. - С. 26-34.

Т.Х. Макажанова, А.С. Базылжанова, О.И. Ульбрихт

\section{Көпбүйірлі конустың нормаль ішкі жиындарының құрылымы туралы}

\begin{abstract}
Мақалада нормаланған кеңістіктегі $K$ көпбүйірлі конусының нормаль дөңес ішкі жиындарының құрылымы зерттелді. $\Omega \subset K$ ішкі жиынының нормальдығы ( $K$ конус мағынасында) $\overline{\Omega-K} \cap K=\Omega$ шартымен анықталды (жиын үстіндегі сызық топологиялық тұйықталу дегенді білдіреді). Конустың көпбүйірлілігі деп шеткі сәулелері болып табылатын сәулелер ақырлы санының канондық қабықшасын айтамыз. Нормаль жиындардың құрылымы геометриялық тұрғыдан зерттелді. Көпбүйірлі конустың кез келген $\Omega$ нормаль ішкі жиынын екі ішкі жиындардың қосындысына бөлуге болатындығы көрсетілді: оның бірі - шектелген нормаль жиын (кейбір $K$ ішкі конус мағынасында), ал екіншісі - $\Omega$ жиынына тиісті $K$ ішкі конусы (егер $\Omega$ шектелмеген болса, онда ол да шектелмеген).
\end{abstract}

Kiлm сөздер: конус, нормаль, конустың қабығы, көпбүйірлі конус, сәулелер құрылымы, жабық жиынтығы, конус қалыпты ішкі жиыны.

Т.Х. Макажанова, А.С. Базылжанова, О.И. Ульбрихт

\section{О строении нормальных подмножеств многогранного конуса}

В статье исследовано строение нормальных выпуклых подмножеств многогранного конуса $K$ в нормированном пространстве. Нормальность подмножества $\Omega \subset K$ (в смысле конуса $K$ ) определяется условием $\overline{\Omega-K} \cap K=\Omega$ (черта над множеством означает взятие топологического замыкания). Многогранность конуса означает, что он является конической оболочкой конечного числа лучей, являющихся крайними лучами. Исследовалось строение нормальных множеств с геометрической точки зрения. Показано, что всякое нормальное подмножество $\Omega$ многогранного конуса можно разбить на сумму двух подмножеств, одно из которых является ограниченным нормальным (в смысле некоторого подконуса в $K$ ) подмножеством, а второе - содержащимся во множестве $\Omega$ подконусом $K$ (неограниченным, если $\Omega$ неограничено).

Ключевые слова: конус, нормаль, коническая оболочка, многогранный конус, образующие лучи, замкнутое множество, нормальное подмножество конуса. 


\section{References}

1 Goldman, A.Dzh., Takker, A.U. (1959). Mnohohrannye vypuklye konusy [Multifaceted convex cones. Collection of articles]. Lineinye neravenstva $i$ smezhnye voprosy - Linear inequalities and related questions: digest of articles. Moscow: Inostrannaia literatura [in Russian].

2 Vulikh, B.Z. (1977). Vvedenie v teoriiu konusov v normirovannykh prostranstvakh [Introduction to the theory of cones in normed spaces]. Kalinin: Izdatelstvo KHU [in Russian]. 